1. FCPS

Professor Medicine

Chandka Medical College Hospital,

Larkana.

2. FCPS

Associate Professor Medicine

Chandka Medical College Hospital, Larkana.

3. FCPS

Consultant Physician

Chandka Medical College Hospital, Larkana.

4. FCPS

Senior Registrar Medicine

Chandka Medical College Hospital, Larkana.

5. FCPS

Senior Registrar Medicine

Chandka Medical College Hospital, Larkana.

6. FCPS

Assistant Professor Medicine Chandka Medical College Hospital, Larkana.

Correspondence Address:

Dr. Azizullah Jalbani

House No 185 ,

Sachal Colony Larkana.

azizjalbani@yahoo.com

Article received on:

30/08/2019

Accepted for publication:

07/11/2019

\section{TO DETERMINE THE FREQUENCYOF HEPATITIS C INFECTION IN PATIENTS WITH ISCHEMIC STROKE AT CMCH LARKANA.}

Hakim Ali Abro ${ }^{1}$, Azizullah Jalbani ${ }^{2}$, Chandur Lal $^{3}$, Sheeraz $\mathrm{Ali}^{4}$, Sultan Ahmed Chandio ${ }^{5}$, Mumtaz Ali Chhutto ${ }^{6}$

ABSTRACT... Objectives: To determine the frequency of Hepatitis $C$ infection in patients with ischemic Stroke at CMCH Larkana. Study Design: Cross-sectional study. Setting: Medical wards of Shaheed Mohtarma Benazir Bhutto Medical University Larkana. Period: From January 2018 to December 2018. Material \& Methods: This study was conducted on 125 diagnosed ischemic stroke patient with age $>18$ years or both genders. Patients with sudden history of partial or complete weakness of half the body persisting for more than 24 hours and clinical examination supporting reduced power and presence of focal sign and CT brain showing hypodense area in respected blood supply. Patients were considered suffering from Hepatitis $C$ who were reactive to anti HCV on second generation ELISA. Results: We surveyed 125 patients admitted with clinical diagnosis of ischemic stroke after exclusion criteria with mean age of $54.53 \pm 10.994$. In this study male were $51.2 \%$ and female were $48.8 \%$. About 40 (32\% patients were anti $\mathrm{HCV}$ reactive. Conclusion: It is revealed that $\mathrm{HCV}$ infection significantly increased the risk of stroke.

Key words: $\quad$ CT-Brain, ELISA, Hepatitis C, Ischemic Stroke.

Article Citation: Abro HA, Jalbani A, Lal C, Ali S, Chandio SA, Chhutto MA. To determine the frequency of Hepatitis $\mathrm{C}$ Infection in patients with Ischemic Stroke at $\mathrm{CMCH}$ Larkana. Professional Med J 2020; 27(1):162-165.

DOI: 10.29309/TPMJ/2020.27.1.4093

\section{INTRODUCTION}

Stroke is episode of focal brain dysfunction due to focal ischemia and hemorrhage. ${ }^{1}$ It is the leading cause of acquired disability in adults in most regions. ${ }^{2,3,4}$ Risk factors like cardiac diseases, hypertension, diabetes, smoking, alcohol intake, unhealthy diet, abdominal obesity, lack of exercise, psychosocial stress and depression carries $90 \%$ stroke risk. ${ }^{3}$ Infectious agents may be considered risk factor for atherothrombosis. ${ }^{5,6,7}$ via their cascade of immune and inflammatory responses either directly in vascular tissue or systemically through mediators. Hepatitis $\mathrm{C}$ virus is a single stranded RNA virus (Hepacivirus) of the Flaviviridae family. ${ }^{8}$ More than 30 extrahepatic manifestations are suggested in HCV infection, out of which transient ischemic attacks, lacunar infarcts,central nervous system vasculitis, encephalopathic syndromes, encephalitis, encephalomyelitis, cryoglobulinemia, ischemic and hemorrhagic stroke are defined neurological manifestations. ${ }^{9,10,11}$ Isolation of intermediates like HCV RNA and viral proteins suggest central nervous viral replication. ${ }^{12}$ Hepatitis $C$ infection isan independent risk factor for increased carotid wall thickness and plaque formationespecially with elevated HCV-RNA levels, thus contributing to significant cerebrovascular mortality. ${ }^{13}$ In study of Taiwan significantly higher incidence of stroke was observed in the HCV cohort than non-HCV cohort of 25.3 vs. 19.3 per 1000 person-years with a unadjusted $\mathrm{HR}$ of $1.30(95 \% \mathrm{Cl} 1.17$ to 1.44). ${ }^{14}$ An other study from Taiwan showed nearly $3 \%$ of $\mathrm{HCV}$ seropositive died due to stroke compared with $1 \%$ of HCV seronegative. ${ }^{15}$ There are few studies conducted on this research topic in Pakistan.

Rationale for this novel study in Pakistan is to see the magnitude of problem, so policy makers could use the information and make the strategy to screen out all the patients of ischemic stroke with Hepatitis $\mathrm{C}$ so that prompt treatment could be initiated to improve recovery in HCV induced 
ischemic stroke and also preventing recurrence of another stroke.

\section{METHODS}

This was cross sectional study conducted at Medical Unit I and Neurology department Chandka Medical College Teaching Hospital Larkana from January 2018 to December 2018.

All the newly diagnosed patients of Ischemic stroke of either gender orage between 18 to 65 years admitted in medical and neurology ward were enrolled in the study. Patients were diagnosed with ischemic stroke when they presented with sudden history of partial or complete weakness of half of the body persisting for more than 24 hours or clinical examination supporting history with decreased power and presence of upgoing planter on affected side and CT scan brain plain showing presence of hypodense area. In all these patients, presence of hepatitis $\mathrm{C}$ Virus infection was confirmed by serological reactivity to anti HCV on second generation ELISA. Patients already diagnosed with diabetes, patients with evidence of atherosclerotic disease like history of previous ischemic stroke with clinical or radiological evidence of jet black hypodense area on CT scan brain plain, history of coronary artery disease like anginal syndrome, myocardial infarction with confirmation on echocardiography, history of carotid artery surgery or angioplasty, patients having symptomatic peripheral vascular disease and abnormal $\mathrm{ABI}$ with any associated surgical history were excluded from the study. Patients known for or incidentally diagnosed with HbsAg seropositivity and found to have dyslipidemia on laboratory reports were also excluded from the study. Except for mentioned in exclusion criteria the other confounding variable of my study are increased Body Mass Index (BMI), cigarette smoking, and history of alcohol intake. All patients were treated in our institution and this analysis was performed after approval from institutional review board.

Data was analyzed on computer using SPSS software version 19.Description statistics like frequency and percentage were compared for gender and outcome, whether presence or absence of anti HCV antibodies. Mean +/-SD (standard deviation) were computed for age and gender. Chi-Square test was applied to see the significance difference between effect modifiers like BMI, cigarette smoking and patients with history of alcohol intake. $P$ value $<0.05$ will be taken as significant.

\section{RESULTS}

This study was conducted on 125 patients diagnosed with ischemic stroke fulfilling the inclusion criteria. The mean age of the patients was $54.53 \pm 10.9$ years and age range was between 18 - 65 years. In this study, the proportion of males was $64(51.2 \%)$ patients, while 61 (48.8\%) were females. From 125 patients of Ischemic Stroke, 40 patients (32\%) came out reactive for Anti HCV while 85 patients (68\%) were non reactive. Majority of these reactive Anti HCV patients were male that is 30 patients (75\%) while only 10 patients (25\%) were female. In young patients less than 40 years of age all were Anti HCV anti body positive. Approximately half of the anti HCV reactive patients were in the age group of 40-60 years. The overall frequencies of risk factors were calculated individually. In study patients, $21 \%$ patients had history of smoking and $21 \%$ of patients had $\mathrm{BMl}>30 \mathrm{~kg} / \mathrm{m}^{2}$, and there was no single patient with history of alcohol intake. Out of these 40 Anti HCV Reactive patients, $30(75 \%)$ were male, while $10(25 \%)$ were females. Approximately 20anti HCV reactive patients were in the age group between $40-60$ years.

\begin{tabular}{|c|c|c|}
\hline Age (Years) & $\begin{array}{c}\text { Anti HCV } \\
\text { Reactive n (\%) }\end{array}$ & $\begin{array}{l}\text { Anti HCV Non } \\
\text { Reactive n (\%) }\end{array}$ \\
\hline$<40$ & $10(25.0 \%)$ & $0(0 \%)$ \\
\hline $40-60$ & $20(50.0 \%)$ & 58 (68.2\%) \\
\hline$>60$ & $10(25.0 \%)$ & 27 (31.8\%) \\
\hline Total Patients & 40 & 85 \\
\hline \multicolumn{3}{|c|}{$\begin{array}{l}\text { Table-I. Distribution of age according to anti HCV } \\
\qquad(n=125)\end{array}$} \\
\hline Gender & $\begin{array}{l}\text { Anti HCV } \\
\text { Reactive }\end{array}$ & $\begin{array}{l}\text { Anti HCV Non } \\
\text { Reactive }\end{array}$ \\
\hline Male & $30(75 \%)$ & 34 (60\%) \\
\hline Female & $10(25 \%)$ & $51(40 \%)$ \\
\hline Total & 40 (100\%) & 85 (100\%) \\
\hline
\end{tabular}

Table-II. Gender distribution of anti HCV $(n=125)$ 


\section{DISCUSSION}

Ischemicstrokeisepisodeoffocalbraindysfunction due to focal ischemia. ${ }^{1}$ Infectious agents may play as a stimulus for atherothromubosis. ${ }^{5,6,7}$ Hepatitis $C$ virus is a single stranded RNA virus of flaviviridae family. ${ }^{8}$ Considering the positivity of HCV RNA in CNS inflammatory syndromes gives evidence of invasion and replication in the CNS ${ }^{16}$ Out of many of the extrahepatic presentation of $\mathrm{HCV}$ infection the following CNS manisfestations i.e. TIA to ischemic stroke and CNS vasculitis are of defined value ${ }^{9,10,11}$

In developed countries $85-90 \%$ of strokes are due to cerebral infarction. The data of frequency of $\mathrm{HCV}$ in ischemic stroke is very limited internationally. ${ }^{14,17}$ Considering the limited data locally as well, our study is of big significance an one of the naiive study.

In our study, Anti HCV waspositive in 32\% of ischemic stroke patient. These positive findings are slightly higher in incidence compare to Taiwan study where cerebral infarct risk in HCV cohort was $25 \%,{ }^{14}$ this higher incidence difference was due to difference in mean age, racial group, sample size, risk factors, prevalence of Hepatitis $\mathrm{C}$ and difference in geographical distribution.

Our study is nearly equal in base line gender distribution as compare to Romania et al. ${ }^{17}$ Our study retrospectively excluded individuals with risk factor for ischemic stroke especially compare to study of Taiwan in which these factors were creating major confounding error. ${ }^{14}$

Secondly as compare to Taiwan study our confounding factors were closely controlled to prevent confounding errors which further statically correlated the association of Hepatitis $\mathrm{C}$ and risk of development of stroke. The final analysis suggested that HCV infection increased the risk of stroke with statistical significance. Thus it is proved that there is a potential association between HCV infection and ischemic stroke. Cerebrovascular disease due to anti HCV had quick functional recovery when treated for hepatitis $C$ and found have no recurrence of stroke. ${ }^{18}$

\section{CONCLUSION}

In conclusion, it is revealed that HCV infection significantly increased the risk of stroke. secondly all patients below age of 40 years were Anti HCV reactive. The results had identified an independent association between HCV infection and risk of stroke. More population based and PCR based studies will be needed to confirm our results. Our study topic only dependent on anti HCV antibody not on PCR.

\section{STRENGTHS OF THIS STUDY}

The main strengths of our study were:

- This is the first study on this topic in south Asia.

- Sample size calculation.

- Exclusion of risk factors of Ischemic stroke such as ischemic heart disease, diabetes mellitus, high BMI, hypertension, hypercholesterolemia, peripheral arterial disease who were anti HCV positive.

- Exclusion co infection with HBV etc from the sample.

- Age and gender wise distribution.

\section{LIMITATIONS OF THIS STUDY}

The main limitations of the study were:

- Our study is limited by its single location in an urban environment.

- Small sample size of this study limits the statistical significance

- A cross sectional study inability to conclude about the causative association.

- A small sample creating problems against generalizability of the results.

- Sample restricted to medical department and hospital.

- No comparison or control group.

- In addition, this study could not provide a disease severity-dependent relationship between HCV infection and stroke.

\section{Copyright $\odot 07$ Nov, 2019.}

\section{REFERENCES}

1. Allen CMC, Lueck CJ, Dennis M. Neurological Disease. In: Colledge NR, Walker RB, Ralston SH. editors. Davidson's principles and practice of medicine. UK: Elsevier 2012; P1131-36. 
2. Feigin VL. Stroke in developing countries: Can the epidemic be stopped and outcomes improved. Lancet NeurolJ. 2007; 6:94-97.

3. Strong K, Mathers C, Bonita R. Preventing stroke: Saving lives around the world. Lancet Neurol J. 2007; 6:182-87.

4. O'Donnell MJ, Xavier D, Liu L, Zhang H, Chin S. Risk factors for ischaemic and intracerebralhaemorrhagic stroke. Lancet J. 2010; 376:112-23.

5. Nieto FJ. Infections and atherosclerosis. Am J Epidemiol. 1998; 148:937-48.

6. Espinola-Klein C, Rupprecht HJ, Blankenberg S, Bickel $\mathrm{C}$, Kopp H, Victor A et al. Impact of infectious burden on progression of carotid atherosclerosis. Stroke. 2002; 33:2581-86.

7. Smeeth L, Thomas SL, Hall AJ, Hubbard R, Farrington $P$, Vallance P. Risk of myocardial infarction and stroke after acute infection or vaccination. $\mathrm{N}$ Engl $\mathrm{J}$ Med. 2004; 351:2611-18.

8. Friend man LS. Liver, biliary tract and pancreas. In: Mcphee SJ, Papadakis MA, editors. Current medical diagnosis and treatment. USA: McGraw Hill; 2008; 566- 609.

9. Origgi L, Vanoli M, Carbone A, Grasso M, Scorza R. Central nervous system involvement in patients with HCV-related cryoglobulinemia. Am JMed Sci. 1998; 315(3):208-10.

10. Ramos-Casals M, Robles A, Brito-Zerón. Lifethreatening cryoglobulinemia: Clinical and immunological characterization of 29 cases. Semin Arthritis Rheum. 2006; 36(3):189-96.
11. Petty GW, Duffy J, Huston J. Cerebral ischemia in patients with hepatitis $\mathbf{C}$ virus infection and mixed cryoglobulinemia. Mayo ClinProc. 1996; 71(7):671-78.

12. Fletcher NF, McKeating JA. Hepatitis $\mathbf{C}$ virus and the brain. J viral Hepat. 2012; 19(5): 301-06.

13. SerenaM, BiscaroR, MorettoG, and RecchiaE. Peripheral and central nervous system involvement in essential mixed cryoglobulinemia: A case report. Clinical Neuropathology. 1999; 10(4):177-80.

14. Liao CC, Su TC, Sung FC, Chou WH, Chen TL. Does Hepatitis $\mathbf{C}$ virus infection increase risk for stroke. A population-based cohort study. PLoSONE. yeeu7 (2):e31527.doi:10.1371/journal.pone.2012; 0031527.

15. Lee $\mathrm{HM}$, Yang $\mathrm{IH}$, Wang $\mathrm{H}$. Hepatitis $\mathbf{C}$ virus infection and increased risk of cerebrovascular disease. Stroke. 2010; 41(12):2894-2900.

16. Bolay $H$, Soylemezoglu F, Nurlu G, et al.: PCR detected hepatitis $\mathbf{C}$ virus genome in the brain of a case with progressive encephalomyelitis with rigidity. Clin Neurol Neurosurg1996, 98:3058.

17. Ishizaka $\mathrm{Y}$, Ishizaka N, Takahashi E. Association between hepatitis $\mathbf{C}$ virus core protein and carotid atherosclerosis. Circ J 2003; 67: 26-30.

18. Marchioni E, Ceroni M, Erbetta A, Alfonsi E, Bottanelli $M$, Imbesi $F$ et al. Severe cerebrovascular disease revealing hepatitis $\mathbf{C}$ virus infection; Effectiveness of alpha interferon. J Neuro. 2002; 249:111-13.

\begin{tabular}{|c|c|c|c|}
\hline \multicolumn{4}{|c|}{ AUTHORSHIP AND CONTRIBUTION DECLARATION } \\
\hline Sr. \# & Author(s) Full Name & Contribution to the paper & Author(s) Signature \\
\hline 1 & Hakim Ali Abro & $\begin{array}{l}\text { Inception and conception of } \\
\text { research corresponding author. }\end{array}$ & \\
\hline 2 & Azizullah Jalbani & $\begin{array}{l}\text { Critical analysis and } \\
\text { corresponding author. }\end{array}$ & \\
\hline 3 & Chandur Lal & $\begin{array}{l}\text { Statistical analysis and drafting } \\
\text { of the manuscript. }\end{array}$ & \\
\hline 4 & Sheeraz Ali & Involved in data collection. & \\
\hline 5 & Sultan Ahmed Chandio & Involved in data collection. & \\
\hline 6 & Mumtaz Ali Chhutto & Involved in data collection. & \\
\hline
\end{tabular}

